\title{
Islamic Corporate Social Responsibility and Patronage of Non-interest Cooperative Societies in North-central, Nigeria
}

\author{
Mustapha Yusuf Ismaila ${ }^{1 *}$, Yahaya Abdulhameed Ahmed ${ }^{2}$, Abduazeez Sodiq \\ Olamilekan $^{3}$, Olowo Ahmed Abdulganiyu ${ }^{4}$ \\ 1, 3,4 Department of Marketing, University of Ilorin, Ilorin, Nigeria \\ ${ }^{2}$ Department of Business Administration, University of Ilorin, Ilorin, Nigeria
}

\section{Keywords}

Islamic Economic Responsibility

Islamic Philanthropic Responsibility

Halāl Products

Halāl Investments

Non-interest Cooperative Societies

Received: 21 April 2021

Accepted: 31 May 2021

\begin{abstract}
.
Purpose: This study interrogates the extent of implementation of economic and philanthropic dimensions of the Islamic Corporate Social Responsibility (ICSR) concept by Sharī'ah based cooperative societies with the primary purpose of ascertaining its effect on members' rate of patronage of non-interest cooperative societies in Nigeria.
\end{abstract}

Methodology: Partial least squares structural equation modelling (PLSSEM) with bootstrap processes were used to analyse the data collected from 210 members of the selected non-interest cooperative societies operating in the North-central region of Nigeria.

Findings: The study's results revealed that halāl products and halāl investments positively affect the members' patronage rate of non-interest cooperative societies. In addition, it was discovered that Islamic philanthropic responsibility influenced the image/reputations of non-interest cooperative societies.

Significance: This study is among the few studies that have examined the effect of corporate social responsibility on members' patronage from an Islamic perspective. The import of the study stems from the fact that it broadly investigated the extent of implementation out of the six dimensions of corporate social responsibility.

Limitations: The main constraints of the study are predicated on the fact that it was conducted in a region of the country and the study's inability to isolate other factors which might have contributed to members' patronage of non-interest cooperative societies.

Implications: The study's findings can aid the management of noninterest cooperative societies and other similar institutions in formulating strategic policies and programmes geared towards operating and promoting halāl investment opportunities and supporting the indigent members of the communities through corporate charities/donations.

KAUJIE Classification: $\mathrm{H} 4,166$

JEL Classification: M12, M5

\footnotetext{
${ }^{*}$ Corresponding author: Mustapha Yusuf Ismaila

†Email: ismyoriss@ gmail.com; ORCID: https://orcid.org/0000-0002-6303-0536
} 


\section{INTRODUCTION}

Corporate social responsibility (CSR) as a management concept has captivated the attention of scholars, business consultants, and organisations over the years (Hassan \& Harahap, 2010). It is maintained that marketing firms exist to satisfy the valuable needs of their target customers and that of the societies in which they operate. Therefore, if a corporate firm desires to remain viable in the long run, it essential to pay adequate attention to societal needs and demands (Muhamad, 2007). In the view of Panwer et al. (2006), CSRs are those activities of companies in accordance with societal demands. It entails all the responsibilities undertaken by firms and their impacts on consumers, workers, stakeholders, the public, and the environment in every facet of their activities (Khatun \& Alautiyat, 2012). Hence, CSR simply emphasises the role of business organisations towards society.

Mustapha and Aun (2015) opined that CSR had been widely adopted as an innovative approach for solving social, environmental, and economic problems to advance benefits to society, including the organisation's stakeholders. This approach is based on the belief that business enjoys many privileges from the community within which it operates; hence, it must pay back either directly or indirectly. Although, Khatun and Alautiyat (2012) observed that exercising businesses' social responsibilities is perceived as expenses, and expenses reduce net profits. This can be inimical to the primary aim of the firms. The proponents of this perspective believe that most firms now regulate their time and efforts to meet social responsibilities because of this thinking.

However, the proponents of CSR maintained that organisation should strike a balance between making a profit and giving back to the environment where the profit is made. This is why Mustapha and Aun (2015) asserted that an interdependent association exists between a firm and its operational environment. The association usually suggests that a firm can merely prosper if it functions in a way beneficial to the generality of shareholders in its operating environment. Supporting this claim, Sanni et al. (2014) observed that organisations' management are now concerned about how to sustain this symbiotic relationship. The sustenance of this has made many firms to be more uncompromising about advancing and promoting efforts to realise more socially responsible decision-making, typically referred to as corporate social responsibilities (CSRs).

Contrarywise, Islam considers social responsibility as an integral part of every society that aims for social, spiritual, and economic achievements for human welfare in this world and hereafter. In fact, Frederick (1994) maintains that religious values and attitudes are vital reasons to raise corporate social responsibility commitments in every society. Almighty Allah (SWT) declared in Surāh 5:2 that...

"And corporate in righteousness and piety, but do not cooperate in sin and aggression. And fear Allah; indeed, Allah is severe in penalty".

Thus, the objective of Islamic-oriented business organisation or cooperative societies should not be chiefly anchored on maximisation of returns but that of pursuing ultimate bliss for her members. Almighty Allah (SWT) says in Surāh 18:46, "Wealth and sons are allurements of the life of this world; But the things that endure, good deeds, are the best in the sight of your Lord, as rewards, and best as the foundation for hopes". Similarly, the noble Prophet 
Muhammad (PBUH) also said: "By spending in charity, the wealth does not decrease... (Muslim, Vol. 4, no: 6264)".

It can be deduced from the divine citations above that there is a guarantee that each benefit sent to society by business organisations will come back to them as a more generous benefit over time (Parvez \& Ahmed, 2004). Islamically, every social responsibility activity implemented by an Islamic cooperative society or any other haläl-oriented business organisations should be seen as an advantage rather than an expense. Lee and Kim (2017) affirmed this position when they opined that a firm that employs premeditated redistribution to the public (CSR) boosts the worth of their firm. El-ghoul et al. (2016) further pointed out that societal and environmental practices enhance a firm's competitive advantage. Therefore, the CSR of the firms operating based on Shar'̄'ah is known as Islamic corporate social responsibility (ICSR). These firms follow Islamic rules and regulations in every aspect of their operations in order to foster the interests of individuals and groups in this world and the hereafter.

Non-interest or Islamic cooperative societies, as business entities are following Sharī'ah rules and regulations, face even additional expectations in executing CSR as Islamic financial institutions. This is why the CSRs attitudes of these firms should be different from their counterpart business entities (interest-based cooperative societies). For instance, some cooperative societies wave off penalty amounts on a member who cannot pay the due or loan obtained at stipulated time. This is because Islam has enjoined her adherents to deal with one another benevolently. Almighty Allah says in Surāh 2:280, "And if the debtor is in difficulty, give him respite till the time of ease; and your foregoing the entire debt from him is still better for you, if only you realise". More so, Prophet Mohammed (PBUH) was reported by Hudhaifa to have said, "Before your time the angels received the soul of a man and asked him, 'Did you do any good deeds (in your life)?' He replied, 'I used to order my employees to 'grant time to the well-off and forgive the needy.' So, Allah said to the angels; excuse him".

Similarly, social responsibility can be extended to Muslims on special occasions, especially during the Ramadān period; an Islamic cooperative society can distribute food items to people to break their fast. Other forms of Islamic social responsibility that cooperative societies can embark on are establishing Islamic training centres; granting scholarships to the less privileged among Muslims or non-Muslims, and sponsoring community projects like street lights, boreholes, drainages, etc. It is expected that these practices would expose Islamic cooperative societies to various benefits, among which are improved financial performance, increased members' commitment, enhanced corporate reputation/image, and good relations with government and communities (Durrani, 2016; Ismail et al., 2012; Othman \& Mia, 2008; Siwar \& Hossain, 2009).

To ascertain the extent to which cooperative societies operating based on Sharī'ah principles have gone in adopting and implementing Islamic corporate social responsibility in Africa and, by extension Nigeria. Specifically, the study examines two dimensions of ICSR: Islamic economic and Islamic philanthropic responsibilities and this is done to enable indepth analysis of these dimensions.

Consequently, the current study investigates the effect of Islamic corporate social responsibility on the patronage/membership level and image/reputation of the cooperative societies in 
North-central Nigeria. The general objective of the study is to examine the effect of Islamic corporate social responsibility on the patronage of non-interest cooperative societies in the North-central region of Nigeria, while the specific objectives are to:

i. examine the effect of Islamic economic responsibility on the patronage rate/level of non-interest cooperative societies; and

ii. determine the extent to which Islamic philanthropic responsibility influences the reputation/image of non-interest cooperative societies.

\section{Islamic Corporate Social Responsibility}

\section{Forms of Islamic cooperate social responsibility}

There is no accord on what should be contained in the organisations' societal responsibilities (Griffin, 2000; Humber, 2002). However, Islam's divine principles provide the best guidelines for organisations regarding CSR (Durani, 2016). In other words, the ethics and regulations that have been fundamental to Islam from our noble Prophet Mohammed (PBUH) might serve as a basis for the concepts of corporate social responsibility (CSR) analogous to those in the western world. This study, therefore, adopts the conceptual model developed by Muhammad et al. (2014), which represents the dimensions of CSR from the Islamic perspective. While this model comprises four dimensions (i.e., Islamic economic responsibility, Islamic legal responsibility, Islamic ethical responsibility, and Islamic Philanthropic responsibility), only two are considered for the present study.

\section{Islamic Economic Responsibility (IER)}

IER includes profit maximisation, legitimate earning, halāl products and services, and halāl investment. It is a general view that every company is in business to make a profit. Meanwhile, Ali et al. (2013) opined that yield assumes a central place in Islamic ethics. Consequently, Islamic prescriptions disregard profit that leads to manipulation and harm in the marketplace. This was highly encouraged by the Prophet when he said: "May Allah show mercy to a man who adopts a kind attitude when he sells, buys and demands for the repayment of loan" (Al-Bukhari: Book 12, hadīth 84/1368).

Moreover, a close look at Islamic history presents a myriad of evidence on the significant concerns for every Muslim's economic wellness. In this regard, Islam legislates many ways to earn a living through legal dealings by which her adherents can make a living. This is to maintain a balance between the struggle for this life and that to come. There are manifestations of this in the Prophet's (PBUH) lives and many of his companions; they engaged in many trading activities while establishing the ethical fundamentals of Islamic business practices at the commencement of the religion (Bhatia, 2004).

Although the experience has shown that financial services form the basis of operation of most Islamic cooperative societies in the North-central region of Nigeria, some of these societies offer a wide range of products to their existing and potential members. These products include food and beverages, personal home care, travel and tours (haji pilgrimage), hospitality, automobile hire purchasing, and mortgage. Yet, Allah has given prescriptions on conducting business transactions to ensure fairness to all and sundry. The basic rule is 
that they should be what the religion of Islam approves of. By implication, neither should such transaction contain any part of matter that the Sharī'ah prohibits. Therefore, Muslims are only allowed to make profits through legitimate and impartial means (Beekun \& Badawi, 2005). They must avoid dealings involving interest, bribery, games of chance, speculation, short weighing, and short measuring and business negligence. Uddin and Karim (2010) also emphasised that expenditures for specific objects, such as alcoholic drinks, debauchery, items that promote obscenity and vulgarity, lotteries and gambling, are sternly prohibited. Thus, Islamic cooperative societies need to be mindful of the dealings which are considered unlawful in the light of the religion as they go a long way in determining the image of the society in the eyes of both present and prospective members.

\section{Islamic Philanthropic Responsibility (IPR)}

According to Muhammad et al. (2014), individuals are expected to guarantee justice to their promoters and well-being to humanity. They further emphasised that companies can fulfill their philanthropic responsibility via donations. These can be provided in cash to help the poor, needy persons, or orphans or build public facilities, such as mosques, public halls, and recreational parks, which will assist the Muslim community. This is based on the fundamental belief that all possessions belong to Allah, the generous giver; human beings are only a trustee and must realise that there is a portion of their wealth that belongs to others around them. Allah says: "And fear Allah as much as you can, listen and obey; and spend in charity for the benefit of your souls. And those saved from the covetousness of their own souls, they are the ones who achieve prosperity" (Surāh 64:16). Therefore, Islam persuades every Muslim to share their wealthy's fortunes with unsuccessful individuals in the community by paying zakāh (alms) and șadaqah (charitable donations). This also extends to Islamic cooperative societies as they are bound to manage resources to the best of their abilities. By so doing, they create maximum value in social responsibility to benefit the community as a whole.

Another way an Islamic cooperative society can fulfill its philanthropic responsibility is to sponsor religious and cultural programs. Islam has urged Muslims to call people to the right path with wisdom and a good sermon. According to Mustaffa et al. (2012), all Muslims are encouraged to perform $d a^{6} w a h$ as part of 'iba $\overline{d a h}$ (worship), for instance, inviting people to Islam and encouraging and spreading good deeds to people. The foundation for this has been laid in numerous verses of the glorious Qur'ān and authentic traditions of the Prophet. Allah says: "Only those are the believers; (those) who have believed in Allah and His Messenger, and afterwards doubt not but strive with their wealth and their lives for the cause of Allah..." (49:15) and "invite people to the way of your Lord with wisdom and fair preaching..." (16:125). Also, when a companion asked the Prophet regarding the one who cannot afford charity by giving out money or helping someone in need, the Prophet replied, "Then he should enjoin the doing of good..." (Sahịh al Bukhari; Hadīth no. 225). Therefore, it behooves every Islamic society to work towards this great endeavour to ensure a high spiritual vibrancy among Muslims. 


\section{Empirical Review}

Islamic CSR research appears to still be at its infancy stage. This is because very few studies have been conducted around the field. It includes Mathkur (2019), who studied the influence of Islamic economics on communal services and social responsibility. The paper aims to determine the critical roles of Islamic economics in advancing the socio-economic development of Saudi Arabia. The study's findings revealed that Islamic economics has aided in enhancing the delivery of community services and disseminating social responsibility activities in the Kingdom of Saudi Arabia. Also, this study showed that Islamic economics had constructively impacted on the social fabric of the Saudi society. Also, Ismail, Alias, and Mohd Rasdi (2012) explored the outcome of corporate social responsibility in Malaysian community development. They identified three vital CSR recipient groups: middle college students, university students, and the public. A simple random sampling technique was utilised to acquire a sample of families and individuals concerned with CSR programs related to three aspects of community development dimensions. Data were obtained via one-on-one interviews with the respondents at the place where they were identified, such as universities, schools, and community halls where they were gathered. The survey data collected were analysed descriptively using frequency distributions and means. The study finding revealed that the respondents' highest orientation is legal responsibility, followed by philanthropic, economic, and ethical responsibilities. However, this was contrary to a study carried out in Malaysia by Abdul Rahim et al. (2010), which discovered that firms' legal and ethical dimensions were recognised as the two feeblest predictors influencing consumer behaviour and economical as well as philanthropic responsibilities were the greatest predictors.

The work of Atan and Abdul Halim (2011) examined the perception of Islamic customers towards CSRs. This work is possibly one of the earliest to surveyed Islamic consumers' perception of corporate social responsibilities, especially in Malaysia, a multi-ethnic Islamic nation. The study extended Carroll's pyramid of four CSR dimensions, economic, legal, ethical, and philanthropic, by incorporating Islamic value as another dimension. An enquiry was carried out through e-mails administered to 700 customers, which were proxied by university staff from three prominent public universities in the capital state of Kelantan. Although the examination was principally aimed at the Islamic stakeholders, Islamic value was not recognised as the utmost imperative CSR dimension. The findings revealed that those shareholders felt legal responsibility to be the foremost significant CSR dimension, trailed by philanthropic, economic, Islamic value, and ethical dimensions. This implies that the respondents abide by the law as they are most concerned with whether or not firms comply with the rules and regulations. It was also found that the Islamic stakeholders expect companies to discharge their philanthropic obligation by aggressively contributing to humanity by improving their quality of life as the religion of Islam directs its ardent to assist each other, particularly the poor and the needy.

Moreover, the studies conducted by Amran and Susela (2007) and Thompson and Zakaria (2004) discovered that dynamic participation in philanthropic activities by firms shows that they recognised the significance of philanthropic responsibility of the firms to the commu- 
nities. This finding had made customers' including Islamic adherents in Kelantan to be more conscious of their expectations from the firms. The study further showed that from the Islamic adherents' point of view, especially in Kelantan, economic responsibility is considered less imperative, although financial performance is essential for the firms to sustain a solid competitive position.

Jusoh and Ibrahim (2015) also anchored research on Malaysian practitioners' overall perception of CSR of Islamic banks. The study selected all 16 Islamic banks in Malaysia, using semi-structured one-on-one interviews to collect respondents' data. It was found that the foremost eight considerations, which accounted for $88.7 \%$, meaningfully influenced the Islamic banks in Malaysia to execute CSR programs. The considerations are "promote corporate image", "top management awareness", "ethical motivation of top management", "genuine philanthropy", "accountability", "greater employee satisfaction", "promotes long-term profits", and "tax deduction". The remaining three considerations, i.e., "legal requirements", "pressure from the public", and "indirect pressure from the government", accounted for $11.3 \%$ frequency of incidences and are reported as not significant considerations. It was also revealed that a reasonable number of the research partakers agreed with the proposition that Islamic banks must obey the obligatory guidelines, which are central to their existence as Islamic banks (obligatory). At the same time, it is recommended that they undertake charitable activities within their capacities.

Also, Durrani (2016) examined the CSR methods of Islamic and conventional banks practising in Pakistan. The data collected for the study involves the assessment of the yearly reports of three (3) conventional banks and three (3) Islamic banks from 2011-2014, respectively. These banks were selected through a random sampling method. The traditional banks are allotting an increased amount on CSR practices, frequently in dimensions like education, environment, collaboration with government, legal issues, and sport. Conversely, Islamic banks tend towards healthiness, arts and culture, water purification, persons with special needs, reprieve and adversity recovery and social welfare. The study similarly discovered that both Islamic and conventional banks are frequently tending towards a philanthropic perspective. There is a need to advance a standard and all-inclusive CSR agenda for both banks concerning CSR practices.

Furthermore, Elhassab et al. (2016) investigated corporate CSR in Islamic economies: The case of Sudan. The study aims to determine if there is any commitment to CSR towards local communities in South Kordofan, Sudan. The study found that firms are more motivated towards communal growth and developmental issues and keen on contributing to economic development arrangements. Moreover, they should be charitable and channel money towards those causes influenced by their political bias.

Being philanthropic is considered the uppermost level of responsibility of a firm after economic, legal and ethical obligations have already been met. These are the classes of activities through which firms might demonstrate accountability to their stakeholders and the society in which they operate. Another study by Mohezar et al. (2016) assessed the growing awareness in managing CSR in the food retailing sector by examining how CSR is entrenched in the retailers' activities. Semi-structured interviews conducted with four hypermarkets in 
Malaysia were used to elicit how CSR is implemented and carried out at the retail store. The findings suggested that CSR's understanding and practice in the hypermarkets within the Malaysian setting are grounded in the context of the environment, food safety, labour, and human rights, community, and sourcing.

Furthermore, Dasuki (2005) assessed the notion of CSR from the Islamic value system within the context based on taqwa (God-consciousness) archetype, maqāsid al-Sharī'ah (the objectives of Shari' 'ah), and where the principles of maslahah served as a basis for understanding the view of Islam on CSR. The study revealed that taqwa archetype encourages a company to constantly operate reasonably and socially, regardless of the monetary outcomes. In contrast, the understanding of maqāsid al-Sharī'ah and the philosophies of maslahah strengthened the significance of CSR. Although this study attempted to elaborate on CSR from an Islamic standpoint, Jusoh et al. (2015) argued that CSR's actual status in Islam remains unrequited. This prompted them to conduct similar research to establish CSR's status in Islam and determine whether or not Islamic banks are answerable for CSR programs.

Meanwhile, they hinted that Islamic bank status is a novel issue that does not have flawless proof from principal sources; hence, it has only been deliberated on lately but indirectly by Muslim intellectuals $\left(f u q a h \bar{a}^{\prime}\right)$. Consequently, authoritative contemporary and conventional fiqh books were employed for the study. The research concluded that Islamic banks share comparable obligations with a natural person and share similar responsibilities with natural Muslim people since Islamic banks are Islamic institutions.

An Islamic bank is a recognised legal entity in Islam, which is, subsequently, responsible for CSR. Moreover, there is a need to organise the training of individuals, particularly entrepreneurs and business executives, on the significance of CSR. The recognition of this is profoundly extolled in one of the founding pillars, zaka $h$ (obligatory charity) of Islam and, therefore, not a strange notion (Mir et al., 2015). The literature review above has exposed that these studies' preponderance is associated with the effect of Islamic social responsibility on Islamic banks without any focus on Islamic cooperative societies. There is, therefore, a need to research in this regard, hence, the objective of this present study.

\section{Theoretical Framework}

Theories related to CSR are numerous and well-known in the extant literature, but four of these theories were briefly discussed in this study.

\section{Classical theory}

The Classical theory, which Milton Friedman strongly influenced, proposed that the solitary social responsibility is to utilise its resources and engage in actions designed to raise its profits. It remains within the game's guidelines - engaging in open and accessible competition without deceit or fraud.

\section{Social contract theory}

Donaldson and Dunfee (1994) also developed the social contract theory that guides managers to take ethical context in making decisions. According to Dasuki (2008), the theory argues that businesses as integral parts of the social structure should meet societal needs. The theory also holds that corporate firms and society have shared interests. This is because the former 
requires support in the form of sales and resources from the latter, and in return, the latter may expect socially responsible behaviour from the former (Lantos, 2001).

\section{Legitimacy theory}

Meanwhile, the legitimacy theory advances that firms pursue to tie their activities with what is seen to be suitable in society. In other words, society's acuity is an actual stimulus for CSR and, thus, is central to the organisation's existence. This is because the society may revoke its social contract with the company if the latter does not satisfy the former's perception (Mir et al., 2015).

\section{Instrumental theory}

Another relevant theory is instrumental theory. According to Dasuki (2008) and Kazi and Hala (2012), this theory asserts that growing and preserving a good reputation via CSR programs may enhance the firm's reputational capital and competitive advantage.

It is apparent that the majority of the theories above are based on the western perspectives, and they are unsuccessful in providing a single ethical rationalisation for their orientation (Dasuki \& Abdullah, 2007). They are also faulty in the aspect of purpose; they contradict Islam's ethics, which encourages Muslims to execute socially responsible programs just for the sake of Allah without expecting any form of monetary or premeditated benefits in response to welfare programs. Allah says: "Those who spend their wealth in the cause of Allah and do not follow up their gifts with reminders of their generosity or with injury, their reward is with their lord. On them shall be no fear, nor shall they grieve (Surāh 2:262). However, the social contract theory expects businesses to act responsibly, not only for commercial interest but also because it is a part of how society implicitly expects businesses to operate. In addition, there is no inherent contradiction between improving the competitive context of business and making a sincere commitment to bettering society (Kazi \& Hala, 2012). The foundation for this can be obtained from the Qur'ān: (Surāh 5:2)... "Help you one another in Al-Birr and At-Taqwa (virtue, righteousness and piety); but do not help one another in sin and transgression..." Thus, the social contract theory is utilised as the theoretical background for the study. This is because the dimensions of corporate social responsibility discussed in the extant conventional literature applied to Islamic financial institutions as long as it is in accord with the spirit and traditions of Islam (Faliza et al., 2019).

\section{METHODOLOGY}

To achieve this study's objective, the descriptive research design was adopted and approached through a survey. The suitability of this stems from its appreciable orientation towards the determination of a given phenomenon. The study population comprises Islamic cooperative societies operating across the North-central region of Nigeria. Therefore, the total population was divided into non-overlapping areas (states), and these non-overlapping areas or states in the region are Kwara, Niger, Benue, Plateau, Kogi, and Nasarawa. Eventually, Kwara, Niger, and Plateau states were chosen through probability sampling methods consisting of cluster and random techniques. Two Islamic cooperative societies operating in these three states were randomly selected to serve as the study population, while members of the cooperative societies were conveniently selected as sample elements of the study. Cluster 
and random sampling techniques, which is its extension, were utilised to select the sample elements in the study area. This was necessary because the study locale is very large, and it was not practicable to cover the whole population. Data were gathered by administering a questionnaire to the selected Islamic cooperative societies' members to extract detailed information on the subject matter and clarify complex issues. The administered questionnaire was, however, separated into two sections namely; sections A and B.

TABLE 1

Demographic Information of the Respondents

\begin{tabular}{llll}
\hline \hline Variables & No. of Responses & Percentage & Cumulative \\
\hline Gender & & & \\
Male & 123 & 64.1 & 64.1 \\
Female & 69 & 35.9 & 100
\end{tabular}

Educational Qualification

School Cert 47

University Degree/HND

PGD/Masters

Ph.D.

Cooperative Societies

Al-Burhan Cooperative Society

75

39.1

39.1

Al-Amana Cooperative Society

Hikmah Cooperative Society

60

57
24.5

24.5

37.5

62

25

13

87

100
70.2

$29.8 \quad 100$

Duration of Membership in Years

$1-5$

6-10

$11-15$

$16-20$
66

86

24

17

Section A contained demographic characteristics of the respondents while section B bordered on questions that are aimed at eliciting the views of respondents on the effect of non-interest corporate social responsibility on patronage of non-interest cooperative societies. Due to the nature of the data collected and more importantly, the objectives of the study, descriptive and inferential statistics were employed. The descriptive statistics include count, frequency and percentage to profile sample characteristics and major pattern of respondents' response to questions. In contrast, the inferential statistics are partial least squares structural equation modelling (PLS-SEM) with bootstrap processes. It was employed to test the extent 
of the effect of Islamic economic responsibility and Islamic philanthropic responsibility on the patronage and image/reputation of Islamic cooperative societies, respectively.

The Islamic economic responsibility was proxied by halāl product and halāl investment, while Islamic philanthropic responsibility was equally proxied by the reputation/image, charities/donations and religious programs of Islamic cooperative societies. The study's data was analysed using Partial least square (projection of latent structures) algorithms and bootstrapping techniques with SmartPLS 3 Statistical software.

\section{Data Presentation and Discussion}

Table 1 shows the demographic characteristics of respondents who are members of the Islamic cooperative societies that were selected for this study. Out of the 192 respondents, 123 $(64.1 \%)$ were males, while $69(25 \%)$ were females. As regards the educational qualification of the respondents, 72 (34.4\%) of the respondents had University Degrees, 47 (24.5\%) of them had SSCE, 48 (25\%) of them had PGD/Master degrees, and 25 (13\%) also claimed to have obtained Ph.D. degrees. This shows that most respondents have obtained a level of education that would enable them to understand the purpose study and are knowledgeable enough to respond to questionnaire items appropriately. For the membership of the studied cooperative societies, 75 (39.1\%) out of the 192 respondents are members of Al-Burhan Cooperative Society in Ilorin, Kwara State, and 60 (31.1\%) said they belong to Al-Amana Cooperative Society, in Lapai, Niger State. The remaining 58 (29.8\%) of the respondents claimed to be members of Hikmah Cooperative Society in Jos, Plateau State. Concerning the duration of membership, the table demonstrates that the majority (44.7\%) of the respondents have been members of their cooperative societies for more than six years. This simply implies that most of the members will give accurate information about Islamic corporate social responsibilities in their respective cooperative societies.

TABLE 2

Construct Reliability

\begin{tabular}{llll}
\hline \hline Construct & $\begin{array}{l}\text { Dijkstra-Henseler's } \\
\text { (a) }\end{array}$ & $\begin{array}{l}\text { Joreskog's rho } \\
\left(p_{A}\right)\end{array}$ & $\begin{array}{l}\text { Cronbach's alpha } \\
\left(p_{c}\right)\end{array}$ \\
\hline Halāl Product & 0.8895 & 0.9300 & 0.8467 \\
Halāl Investment & 0.7958 & 0.8750 & 0.7832 \\
Charity/Donations & 0.7042 & 0.7583 & 0.5733 \\
Religious Programmes & 0.8447 & 0.9048 & 0.8425 \\
Patronage & 0.8581 & 0.9096 & 0.8866 \\
Image/Reputation & 0.7663 & 0.8037 & 0.7106 \\
\hline \hline
\end{tabular}

According to Henseler and Chin (2010), PLS-SEM is widely utilised in social sciences and humanities fields as a data analysis tool and in line with this opinion, the current study also adopts the PLS path modelling. Table 2 shows the reliability of the latent constructs of the research instrument items used in the study. Composite reliability is measured through Dijkstra-Henseler's rho (pA), Joreskog's rho (pc), and Cronbach's alpha $(\alpha)$ in PLS. The rho 
(pA) is the most reliable test for consistent reliability in PLS (Dijkstra \& Henseler, 2015). Usually, the minimum threshold score for consistent reliability is 0.7 . From the table, all the component variables are more than the threshold (0.7).

In the view of Henseler et al. (2016), HTMT value ought to be below 0.85 to 0.90 to have discrimination between constructs. The contents of the tables above, tables 3 and 4, obviously indicate no discriminant validity occurs amongst the constructs.

\section{Hypothesis I}

The path model of the variables of interest in this study is shown below;

TABLE 3

Discriminant Validity Heterotrait-Monotrait (HTMT) Ratio of Correlations

\begin{tabular}{llll}
\hline \hline Construct & Patronage & Haläl Products & Haläl Investment \\
\hline Patronage & & & \\
Halāl Products & 0.7680 & & \\
Hialāl Investments & 0.8393 & 0.8510 & \\
\hline \hline
\end{tabular}

TABLE 4

Discriminant Validity Heterotrait-Monotrait (HTMT) Ratio of Correlations

\begin{tabular}{llll}
\hline \hline Construct & Image Reputation & Charities/Donation & Religious Program \\
\hline Image/Reputation & & & \\
Charities/Donation & 0.7586 & & \\
Religious Program & 0.3867 & 0.8312 & \\
\hline
\end{tabular}

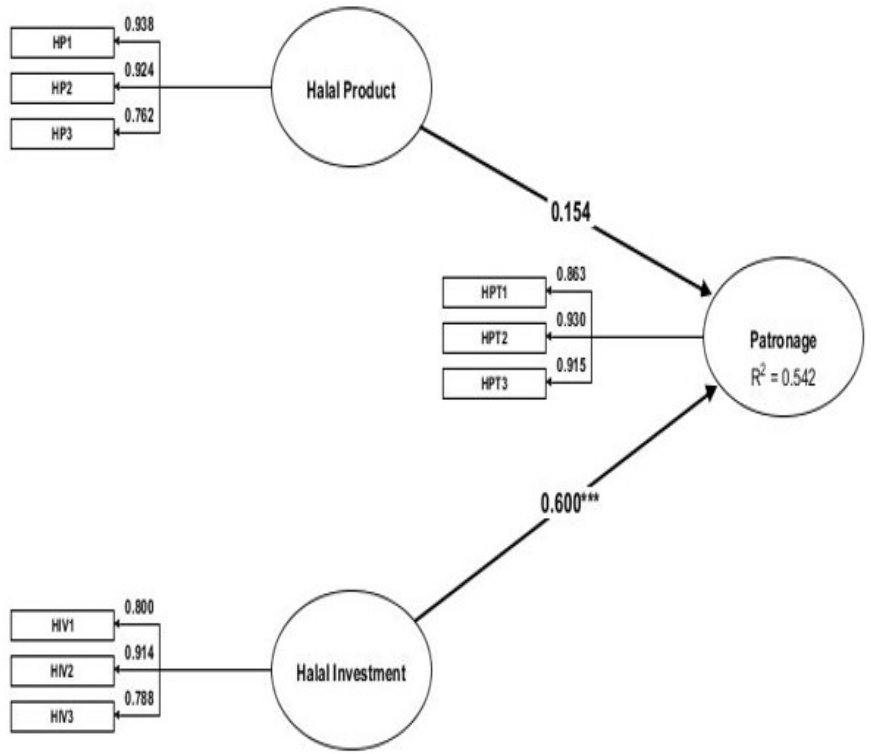

FIGURE 1. Path Model of Islamic Economic Responsibility on the Patronage Rate of Non-Interest Cooperative Society's Path Model 
TABLE 5

PLS Path Coefficients

\begin{tabular}{ll}
\hline \hline Independent Variable & $\begin{array}{l}\text { Dependent Variable } \\
\text { Patronage }\end{array}$ \\
\hline Halāal Product & 0.1542 \\
Ḥalāl Investment & 0.6004 \\
\hline \hline
\end{tabular}

Figure 1 shows the path model analysis of Islamic economic responsibility on the patronage rate of non-interest cooperative societies. Islamic economic responsibility variables adopted for the study are halāl product and haläl investment. These variables were checked against the patronage rate of non-interest cooperative societies. The above figure presents interaction effects where more than single variables contribute to the latent variables.

The path coefficients table 5 shows that the haläl product and halāl investment positively contribute to the latent variable. The absolute magnitude of halāl investment gives a better coefficient of approximately thrice than the halāl product variables. Thus, it implies that both variables are good models for predicting the patronage rate of non-interest cooperatives societies. The identified variables contribute significantly to the prediction of the level of patronage in the study areas.

TABLE 6

Outer Loadings

\begin{tabular}{llll}
\hline \hline Indicator & Patronage & Halāl Product & Halāl Investment \\
\hline HP1 & & 0.9377 & \\
HP2 & & 0.9243 & \\
HP3 & & 0.7622 & \\
HPT1 & 0.8631 & & \\
HPT2 & 0.9302 & & \\
HPT3 & 0.9151 & & 0.8001 \\
HIV1 & & & 0.9143 \\
HIV2 & & & 0.7882 \\
HIV3 & & & \\
\hline \hline
\end{tabular}

The outcome outputs in table 6 exposed that all the outer loadings for all the identified variables were more significant than the criterion for minimum measurement loading yardstick of 0.7. The implication of this is that none of the variables of Islamic economic responsibility and members' rate of patronage is droppable. The outer weight model varies from zero to an absolute maximum lower than 1 , it has been established that the more the indicators for a latent variable, the lower the maximum and the lower the average outer model weight. The results of outer model weights confirm that all the weights were less than 0.05 . These variables were a major constituent of the latent variables from the literature. 
TABLE 7

R-Squared

\begin{tabular}{lll}
\hline \hline & Coefficient of determination & Adjusted \\
Construct & $R^{2}$ & $R^{2}$ \\
\hline Patronage & 0.5418 & 0.5365 \\
\hline \hline
\end{tabular}

The common effect size measure in the path shows the R-square of 0.542 , which implies that $54.2 \%$ of the variance in the rate of patronage can be explained by the joint model of Islamic economic responsibility proxies by halāl product and halāl investment. This is a moderate effect as the identified variables influenced the patronage rate, implying that the remaining $45.8 \%$ is due to other variables not imputed in the model. There is no multicollinearity problem as tolerance in this data set is greater than 0.25 at the extreme. The adjusted R-square is 0.537 , and this is close to the value of the unadjusted $\mathrm{R}$ square in this model. This is because of the inconsequential number of variables captured in the model.

TABLE 8

Bootstrapping Path Coefficients (Total effect inference)

\begin{tabular}{lllllllll}
\hline \hline & & \multicolumn{3}{c}{ Standard Bootstrap Results Percentile } & \multicolumn{2}{c}{ Bootstrap Quantiles } \\
\hline \hline Effect & coefficient & Mean value & Standard error & $\mathrm{t}$-value & $p$-value (2-sided) & p-value (1-sided) & $0.5 \%$ & $2.5 \%$ \\
\hline $\begin{array}{l}\text { Halā } \text { Product } \\
->\text { Patronage }\end{array}$ & 0.154 & 0.15 & 0.141 & 1.091 & 0.276 & 0.138 & -0.19 & -0.12 \\
$\begin{array}{l}\text { Haläal Investment } \\
->\text { Patronage }\end{array}$ & 0.6 & 0.597 & 0.144 & 4.184 & 0.000 & 0.000 & 0.211 & 0.306 \\
\hline \hline
\end{tabular}

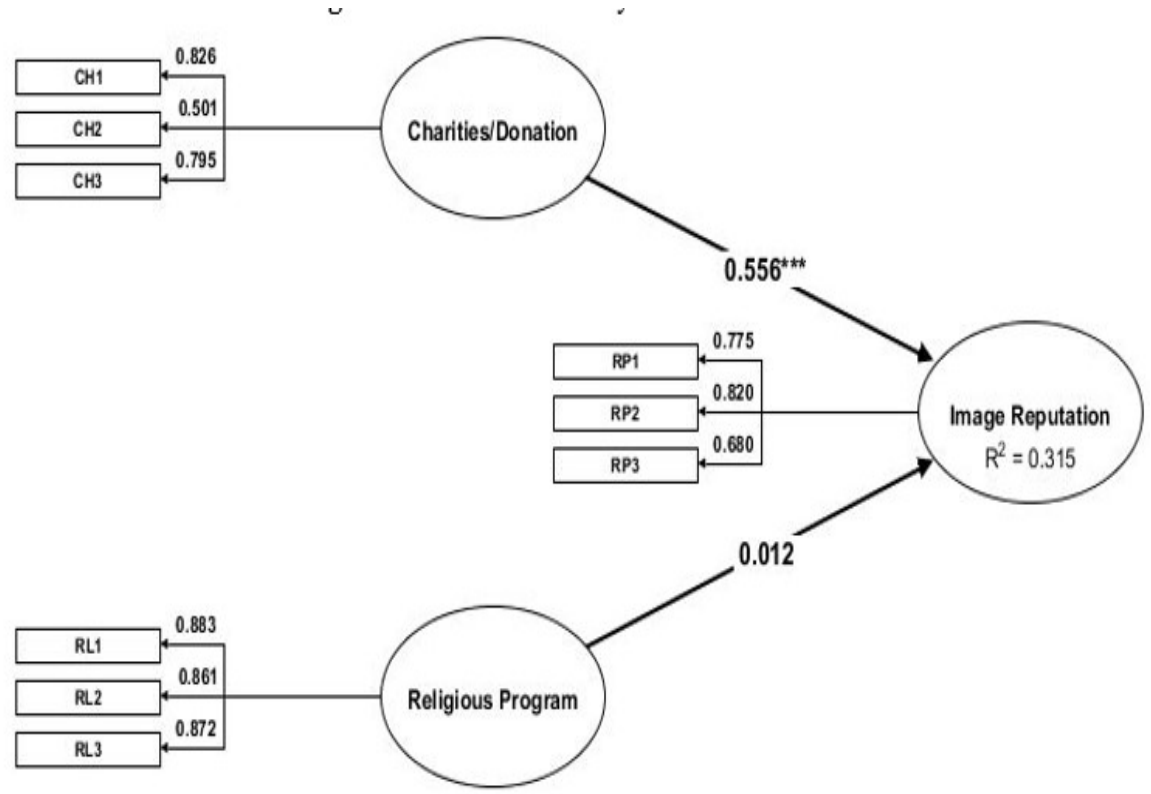

FIGURE 2. Path Model Analysis of the Influence of Islamic philanthropic responsibility on the image/reputations of non-interest cooperative societies 
Table 8 shows the structural path analysis and describes the direct effects of interference tested by two-tailed tests. The PLS bootstrapping output showing the $t$ and $p$ values revealed that the t-value of haläl product is less than 1.96, which implies that halāl product is not significant at a 5\% significance level. In contrast, the t-value of haläl investment is significant. From the output result, it was observed that the haläl investment value is more than 1.96 yardstick which implies that an improvement in the Islamic economic responsibility through the involvement of cooperative societies in haläl investments would go a long way in increasing the level of patronage by their members.

This could not have been otherwise, since one of the main reasons people prefer Islamic cooperative society to their conventional counterparts is to ensure lawful disbursement of their wealth. Famet, Waller, and Erdogan (2004) had observed vehemently that the function of religious beliefs could not be avoided or ignored as religious affiliation inclines to influence the way individuals live, whom they associate with, and what they eat. Consequently, non-interest cooperative societies need to ensure that funds are invested in businesses in total compliance with the Sharīa ah rulings. It is expected that this practice will attract more members and, of course, a high level of patronage in societies.

\section{Test of Hypothesis II}

Figure 2 shows the path model analysis of Islamic philanthropic responsibility's influence on the reputation/image of non-interest cooperative societies. Islamic philanthropic responsibility variables adopted for the study are charities/donations and religious programs. These variables were checked against the image/reputations of the cooperative societies. The figure presents interaction effects where more than a single variable contributes to the latent variables.

TABLE 9

PLS Path Coefficients

\begin{tabular}{ll}
\hline \hline & $\begin{array}{l}\text { Dependent Variable } \\
\text { Independent Variable }\end{array}$ \\
Image Reputation \\
\hline Charities/Donations & 0.5555 \\
Religious Programs & 0.0120 \\
\hline \hline
\end{tabular}

The findings from the path coefficients in table 9 show that charities/donations and religious programs positively contribute to the latent variable. The absolute magnitude of charities/donations gives a better coefficient, approximately twice the concentration on religious programs. Thus, it implies that both variables are good models for predicting the image/reputation of Islamic cooperatives societies. The identified variables contribute significantly to predicting Islamic cooperatives' image and reputations in the sampled area.

From the result outputs in table 10, all the identified variables' outer loadings were all greater than the criterion for minimum measurement loading yardstick of 0.7 except for $\mathrm{CH} 2$ and RP3 (charities/donations and religious programs). These variables could have been dropped from the model, but they are the main constituents' variables in the literature for 
charities and religious programmes. These variables are not droppable, and besides, the outer weight model for these identified variables was also low. Still, due to their relevancy in the literature, the two variables cannot be dropped. These variables were a major constituent of the latent variables from the literature.

TABLE 10

Outer Loadings

\begin{tabular}{llll}
\hline \hline Indicator & Image Reputation & Charities/ Donation & Religious Program \\
\hline CH1 & & 0.8265 & \\
CH2 & & 0.5005 & \\
CH3 & & 0.7947 & \\
RP1 & 0.7749 & & \\
RP2 & 0.8201 & & \\
RP3 & 0.6801 & & 0.8826 \\
RL1 & & & 0.8606 \\
RL2 & & & 0.8723 \\
RL3 & & & \\
\hline
\end{tabular}

TABLE 11

R-Squared

\begin{tabular}{lll}
\hline \hline Construct & Coefficients $R^{2}$ & Adjusted $R^{2}$ \\
\hline Image/reputation & 0.3149 & 0.3070 \\
\hline
\end{tabular}

The common effect size measure in the path in table 11 shows the $R^{2}$ of 0.315 , which implies that $31.5 \%$ of the variance in Islamic cooperatives image/reputation can be explained by the joint Islamic philanthropic responsibility model proxies by charities/donations and religious programs. This is a weak effect $(<0.35)$ as the identified variables influenced the image/reputations of studied cooperative societies. This implies that the remaining $65 \%$ is due to other variables not attributed in the model. There is no multicollinearity problem as tolerance in this data set is greater than 0.25 at the extreme. The adjusted $R^{2}$ is 0.307 . The adjusted $R^{2}$ is close to the unadjusted $R^{2}$ in this model because of the small number of variables.

TABLE 12

Bootstrapping Path Coefficients (Total effect inference))

\begin{tabular}{|c|c|c|c|c|c|c|c|c|}
\hline & & \multicolumn{5}{|c|}{ Standard Bootstrap Results Percentile } & \multicolumn{2}{|c|}{ Bootstrap Quantiles } \\
\hline Effect & coefficient & Mean value & Standard error & t-value & $\bar{p} p$-value (2-sided) & p-value (1-sided) & $0.5 \%$ & $2.5 \%$ \\
\hline $\begin{array}{l}\text { Charities/Donation - } \\
>\text { Image Reputation }\end{array}$ & 0.5555 & 0.5586 & 0.0881 & 6.3084 & 0.0000 & 0.0000 & 0.02898 & 0.3643 \\
\hline $\begin{array}{l}\text { Religious Program - } \\
>\text { Image Reputation }\end{array}$ & 0.0116 & 0.0263 & 0.0850 & 0.1359 & 0.8919 & 0.4460 & -0.1688 & 0.1315 \\
\hline
\end{tabular}

The PLS bootstrapping output showing the $t$ and $p$ values revealed that the $t$-value of religious programs is less than 1.96 , which implies that religious programs are not significant 
at a 5\% significance level while the t-value of charities/donations is significant. From the output result, it was observed that the contributions of the religious program to the image and reputations are not significant. This may be because people now have more access to religious information. Currently, the digital space presents ample opportunities for Muslims to learn about their religion through numerous online platforms such as Facebook, WhatsApp, YouTube, etc., which is even more convenient and affordable for them. In essence, religious programs' ubiquity may cause members to pay little attention to the cooperative societies that offer such philanthropic services to them. The implication, therefore, is that cooperative society need to relax efforts on the religious program and pay more attention to charities/donations programs, as evident in the result that the variable is very significant.

\section{Discussion of the Findings}

The study aimed to establish the degree to which Islamic corporate responsibility impacted the patronage level and image/reputations of non-interest cooperative societies in the study area. For the first hypothesis, table 7 shows that the R-square coefficient of determination is approximately 0.54 , indicating a positive relationship between Islamic economic responsibility and patronage level of Islamic cooperative societies. This suggests that the delivery of Islamic economic responsibility explains approximately $54 \%$ change in the rate of patronage. Table 5 further shows that the PLS path coefficients of the two proxies of the independent variable (halāl product and haläl investment) are 0.1542 and 0.6004 , respectively. Since the values are positive, it can be inferred that involvement in Islamic economic responsibility collectively determines the cooperative society's patronage level. Previous studies conducted by Mathkur (2019) revealed that Islamic economics has aided in enhancing the provision of community services and disseminating social responsibility programs in the Kingdom of Saudi Arabia. Abdul Rahim et al. (2010) found that economic responsibility is the strongest predictor of consumer behaviour related to patronage in an Islamic cooperative society. However, Amran and Susela (2007) discovered that Muslim stakeholders in Kelantan state considered economic responsibility less significant. It is worthy of mentioning that the above studies considered economic responsibility from a general perspective without examining, in particular, the proxies of the variable, such as halāl product and haläl investment. Therefore, the contradictions between these studies' findings may be attributed to the disparity in the extent of the impact of various proxies of Islamic economic responsibility. It is obvious from the present study's results that halāl investment has significant effect on members' patronage, while the haläl product does not.

Also, the coefficient of the independent variables in hypothesis II is positive. This is shown in table 11, where the value of the coefficient of determination R-Square is 0.315 , which is approximately $32 \%$. This implies that $32 \%$ of Islamic cooperatives' image/reputation variance can be explained by the joint model of Islamic philanthropic responsibility proxies by charities/donations and religious programs. This is a weak effect $(<0.35)$ as the identified variables influenced the image and reputations of studied cooperative societies. This implies that the remaining $65 \%$ is due to other variables not imputed in the model. This study's finding agrees with the previous studies findings, such as Atan and Abdul Halim 
(2011), which reported that the Muslim stakeholders expect companies to discharge their philanthropic responsibility by actively contributing to the community in order to improve the humanity's quality of life as Islam orders its adherent to assist one other particularly the indigent. It also agrees with Elhassab et al. (2016) findings that being philanthropic is seen as the uppermost level of responsibility of a firm after economic, legal and ethical responsibilities have been met. Islamic philanthropic responsibility is the class of actions through which firms might demonstrate answerability to their shareholders and the society in which they operate (Elhassab et al., 2016).

\section{Conclusion and Recommendations}

Two of the dimensions of Islamic corporate responsibility are Islamic economic and Islamic philanthropic social responsibilities were evaluated against members' rate of patronage and the image of non-interest cooperative societies in the areas under study. The discussion of findings above shows that there is incoherence in the significance of constituents of the independent variables (Islamic economic responsibilities and Islamic philanthropic responsibilities) that were considered in each of the models developed to test the study's hypotheses. In other words, although all the coefficients of the independent variables are positive, the coefficient of two variables (i.e., hala $\bar{l}$ product and religious programs) in each of the models are not statistically significant, thus, precluding the emergence of a watertight conclusion from this study. Be that as it may, it can be resolved confidently that Islamic economic responsibilities (haläl investment opportunities) affect members' patronage. Also, Islamic philanthropic responsibilities (religious/cultural activities) significantly influence patronage level and image/reputation of non-interest cooperative societies, respectively. Precisely and based on the empirical findings, this study recommends that:

i. Management of Islamic or non-interest cooperative societies should proactively exploit the potentials of Islamic economic responsibilities ( $h a l a \bar{l} l$ investment) as a means of eliciting members' patronage in their operational strategies and programmes. This could be done by formulating policies and programmes geared towards operating and promoting halāl investment opportunities for members.

ii. The management of Islamic cooperative societies should also concentrate their philanthropic social responsibilities on charities/donations to the needy people and indigent members of the communities. These charities and donations could be given in food items, boreholes, scholarships, classrooms, drugs and health facilities, building and renovation of mosques, etc.

iii. Finally, Islamic cooperative societies should be cautious when developing policies for Islamic corporate social responsibilities. This is because the nature of findings revealed by this study does not allow for generalisation. Invariably, there is a tendency that some of the proxies of the independent variables may not yield the desired result in some situations.

\section{REFERENCES}

Abdul Rahim, R., Jalaludin, F. W., \& Tajuddin, K. (2010). Consumer behaviour towards corporate social responsibility in Malaysia. Paper presented at the International Conference 
on Business and Economic Research (ICBER), Kuching, Malaysia.

Ali, A. J., Al-Aali, A., \& Al-Owaihan, A. (2013). Islamic perspectives on profit maximization. Journal of Business Ethics, 117(3), 467-475.

doi: https://doi.org/10.1007/s10551-012-1530-0

Amran A., \& Susela, S. (2007). Corporate social reporting in Malaysia: An institutional perspective. World Review of Entrepreneurship Management and Sustainable Developmet, 3(1), 20-36. doi: https://doi.org/10.1504/WREMSD.2007.012128

Atan, R., \& Abdul Halim, N. (2011). Corporate social responsibility: The perception of Muslim consumers. Paper presented at the International Conference on Islamic Economics and Finance, Qatar: Center for Islamic Economics and Finance, Qatar.

Beekun, R. I., \& Badawi, J. A. (2005). Balancing ethical responsibility among multiple organisational stakeholders: The Islamic perspective. Journal of Business Ethics, 60(2), 131-145.

Bhatia, A. (2004). CSR: An Islamic perspective. Paper presented at the Singapore/UK Developing Corporate Social Responsibility Conference, Singapore.

Dijkstra, T. K., \& Henseler, J. (2015). Consistent and asymptotically normal PLS estimators for linear structural equations. Computational Statistics $\mathcal{E}$ Data Analysis, 81, 10-23. doi: https://doi.org/10.1016/j.csda.2014.07.008

Donaldson, T., \& Dunfee, T. W. (1994). Toward a unified conception of business ethics: Integrative social contracts Theory. Academy of Management Review, 19(2), 252-284.

Dusuki A. (2005). Corporate social responsibility of Islamic banks in Malaysia: A synthesis of Islamic and stakeholders' perspectives (Ph.D. dissertation). Loughboroug University, Loughborough, UK.

Dusuki, A. W., \& Abdullah, N. I. (2007). Maqasid al-Sharī'ah" ah, maslahah and corporate social responsibility. The American Journal of Islamic Social Sciences, 24(1), 25-45. doi: https://doi.org/10.35632/ajiss.v24i1.415

Dusuki, A. W. (2008). What does Islam say about corporate social responsibility? Review of Islamic Economics, 12(1), 5-28.

Durrani B. (2016). Islamic concept and contemporary corporate social responsibility: Comparative study between Islamic banks and conventional banks in Pakistan. Journal of Managerial Sciences 10(2), 317-332.

El-Ghoul, S., Guedhami, O., \& Kim, Y. (2017). Country-level institutions, firm value, and the role of corporate social responsibility initiatives. Journal of International Business Studies, 48, 360-385. doi: https://doi.org/10.1057/jibs.2016.4

Elhassab A., Elhassab, O.' \& Yahya, A. M. (2016). Corporate social responsibility in Islamic Economies: The Case of Sudan. Chr. Michelsen Institute, Bergen, Norway.

Faliza N., Adam M., Basri H., \& Abd. Madjid M. S. (2019). Corporate social responsibility in Islamic and conventional view: A theoretical approach in social sciences on sustainable development for world challenge. Paper presented at the The First Economics, Law, Education and Humanities International Conference, KnE Social Sciences.

Famet, K., Waller, D., \& Erdogan, B. (2004). The influence of religion on attitudes towards the advertising of controversial products. European Journal of Marketing, 38, 537-555. 
Frederick, W. C. (1994). From CSR to CSR the maturing of business and society thought. Business and Society, 33, 150-164.

doi: https://doi.org/10.1177/000765039403300202

Griffin, J. J. (2000). Corporate social performance: Research directions for the 21st century. Business $\mathcal{F}$ Society, 39(4), 479-491. doi: https://doi.org/10.1108/17538391011072417

Hassan, A., \& Harahap, S.S. (2010). Exploring corporate social responsibility disclosure: The case of Islamic banks. International Journal of Islamic and Middle Eastern Finance and Management, 3(3), 203-227.

Henseler, J., \& Chin, W. W. (2010). A comparison of approaches for the analysis of interaction effects between latent variables using partial least square path modeling. Structural Equation Modeling, 17(1), 82-109. doi: https://doi.org/10.1080/10705510903439003

Henseler, J., Hubona, G., \& Ray, P. A. (2016). Using PLS path modeling in new technology research: updated guidelines. Industrial Management $\mathcal{F}$ Data Systems, 116(1), 2-20. doi: https://doi.org/10.1108/IMDS-09-2015-0382

Humber, J.M. (2002). Beyond stockholders and stakeholders: A plea for corporate moral autonomy. Journal of Business Ethics, 36(3), 207-221.

Ismail M., Alias, S. N., \& Mohd Rasdi R. (2012). Community as stakeholder: Exploring corporate social responsibility outcome in Malaysian community development. Paper presented at the British Academy of Management (BAM) Conference, Cardiff, UK.

Jusoh, W., \& Ibrahim, U. (2015). Corporate social responsibility of Islamic banks: Malaysian practitioners perspective. International Conference on Islamic Economics and Finance. International Organization for Research and Development, Istanbul, Turkey.

Jusoh W., Ibrahim U., \& Napiah, M. (2015). An Islamic perspective on corporate social responsibility of Islamic banks. Mediterranean Journal of Social Sciences, 6(2), 308315.

Kazi M., \& Hala A. (2012). Corporate social responsibility: An Islamic perspective. International Journal of Business and Technopreneurship, 2(3), 415-433.

Khatun, K. M. \& Alautiyat, H. (2012) Corporate social responsibility: An Islamic perspective. International Journal of Business and Technopreneurship, 2(3), 415-434.

Lantos, G. P. (2001). The boundaries of strategic corporate social responsibility. Journal of Consumer Marketing, 18(7), 595-632. doi: https://doi.org/10.1108/07363760110410281

Lee, M., \& Kim, H. (2017). Exploring the organisational culture's moderating role of effect of corporate social responsibility (CSR) on firm performance: Focused on corporate contributions in Korea. Sustainability Journal, 9, 1-18.

doi: https://doi.org/10.3390/su9101883

Mathkur, N. M. M. (2019). The impact of Islamic economics on community services and social responsibility in Saudi Arabia. International Journal of Economics, Commerce and Management, 7, (3), 138-148.

Mir, U., Hassan, S., \& Hassan, S. (2015). Islamic perspective of corporate social responsibility. AL-ADWA 46(31), 77-90. 
Mohammed, J. (2007). Corporate social responsibility in Islam (Ph.D. dissertation). Auckland University of Technology, Auckland, New Zealand.

Mohezar S., Nazri, M., Kader M. R., Ali, R., \& Yunus N. K (2016). Corporate social responsibility in the Malaysian food retailing industry: An exploratory study. International Academic Research Journal of Social Science, 2(1), 66-72.

Muhammad, A., Abdulrahman A., Ahmed A., \& Salmiah M. (2014). Developing an Islamic corporate social responsibility model (ICSR). Competitiveness Review 24(4), 258-274

Mustaffa, M.Z., Faizah, D., Haslinda, Y., Azlan, A., Hasan, F., Yadi, P., \& Dayang, M., \& Abang, N. (2012). Corporate ibadah. Paper presented at the Terengganu International Business and Economics Conference, Primula Beach Hotel, Kuala Terengganu, Malaysia. Mustapha, Y. I., \& Aun, I. I. (2015) Corporate social responsibility and organisational productivity: A study of MTN Nigeria limited, Ilorin, Kwara State. Ilorin Journal of Marketing, 1(1), 168-182

Othman, A., \& Mia, B. (2008). Corporate social responsibility for solving the housing problem for the poor in South Africa. Journal of Engineering, Design and Technology, 6(3), 237-257

Panwar, R., Rinne, T., Hansen, E., \& Juslin, H. (2006). Corporate responsibility: Balancing economic, environmental, and social issues in the forest products industry. Forest Products Journal, 56(2), 4-13.

Parvez, Z., \& Ahmed, P. (2004). An Islamic perspective on the lack of social responsibility in business organisations. Retrieved from http://www.wlv.ac.uk/umbs

Sanni, M., Kadir, O., \& Zayyad, A. (2014) Corporate social responsibility and profitability of selected deposit money bank in Nigeria: A panel analysis. Ilorin Journal of Management Sciences, 2, 221-235 Siwar, C., \& Hossain, M. T. (2009). An analysis of Islamic CSR concept and the opinions of Malaysian managers. Management of Environmental Quality, 20(3), 290-298. doi: https://doi.org/10.1108/14777830910950685

Thompson, P., \& Zakaria, Z. (2004). Corporate social responsibility reporting in Malaysia: Progress and prospects. Journal of Corporate Citizenship, 13, 125-136. doi: https://doi.org/10.9774/GLEAF.4700.2004.sp.000014

Uddin, S. K., \& Karim, M. (2010). Corporate social responsibility: Contemporary thought and Islamic perspectives. Thoughts on Economics, 21(1), 45-66. 